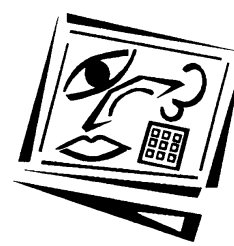

\title{
Assessment of online reflections: Engaging English second language (ESL) students
}

\author{
Dawn Birch and Michael Volkov \\ University of Southern Queensland
}

\begin{abstract}
Online discussion boards are being used increasingly by tertiary educators as a tool for encouraging greater student interaction and developing learning communities. In particular, educators who have adopted a learner centered, socio-constructivist approach to teaching have sought to facilitate collaborative learning in which students reflect upon and share their experiences and perspectives, and construct knowledge together through developing shared meanings. This paper presents the findings of an electronic survey of the perceptions of 70 distance education EFL and ESL students concerning a compulsory assessment item involving contribution to an online course discussion board. The study revealed that the majority of the students enjoyed the assessment item and agreed that posting to the online course discussion board had allowed them to achieve a range of cognitive and social learning outcomes, as well as to develop some important graduate skills. In particular, ESL students reported the benefits of posting to the discussion board in terms of sharing their experiences with others and reducing the feeling of isolation. Further, when considering social outcomes, ESL students perceive the discussion board provided them with an opportunity to meet and develop a closer relationship with other students in the course and encouraged them to keep up with their studies.
\end{abstract}

\section{Introduction}

Online discussion boards are now commonly used in many university courses and, in particular, to provide a communication forum for distance learning students. Indeed, electronic means of communication have overcome the tyranny of distance by providing a flexible mechanism for both native speakers of English (EFL) and students for whom English is not their native language (ESL) to interact with one another at a time and place that is convenient to them (Berge \& Collins, 1993; Harasim, 1987; Whatley \& Bell, 2003; Wu \& Hiltz, 2004). Student interaction on online discussion boards facilitates a learner centered, socio-constructivist approach to teaching involving social and collaborative learning processes (Althaus, 1997; Stacey, 2002; Turcotte \& Laferriere, 2004). Moreover, given the 
difficulties that some ESL students experience in articulating views and perspectives in English, online discussion provides these students with an opportunity to practice the vocabulary of their discipline and develop 'linguistic flexibility' in an encouraging and supportive learning environment (Biesenbach-Lucas, 2003). The main objectives of the study reported in this paper were to explore and compare EFL and ESL distance education students' perceptions toward compulsory participation in online discussions, and to determine the impact of online discussions on perceived cognitive and social learning outcomes.

\section{Literature review}

The social constructivist paradigm emphasises learner centered learning, where learners share their experiences and perspectives with one another, and then negotiate and arrive at shared meanings and perspectives (Goodyear, 2001; Kolb, 2004; Markel, 2001; Whatley \& Bell, 2003; Wilson \& Stacey, 2004). Students are encouraged to collaborate and engage in active dialogue to construct knowledge by discovering principles for themselves (Bruner, 1990; Jonassen, 1990). Providing students with an opportunity to extend their current knowledge (scaffolding) by encouraging them to actively engage in dialogue with other students and instructors (reciprocal teaching), rather than simply requiring them to answer questions, supports the socio-constructivist paradigm (Hausfather, 1996). Moreover in this paradigm, the role of the teacher has shifted away from one way information transfer, toward facilitation of student centered learning through greater emphasis on peer interactions for cognitive development (Curtin, 2002). Social interaction influences cognitive development and is important for raising the quality of distance learning programs (Moore, 1989; Vygotsky, 1978; Wilson \& Stacey, 2004). While the socio-constructivist approach can be readily achieved in face to face teaching environments, it has been more difficult to emulate in the distance education context. However, with the emergence of online discussion forums, students who are studying at a distance are now able to develop learning communities, share and reflect upon their experiences and perspectives, provide feedback to one another, and clarify their ideas (Weasenforth, BiesenbachLucas \& Meloni, 2002; Wilson \& Stacey, 2004).

Studies have revealed that online discussions improve students' perceptions of learning, in terms of learning skills and the quality of their learning (Harasim, 1987; Wu \& Hiltz, 2004). Indeed, online discussions have been found to result in superior learning and reflection because they place students in "an intellectual environment that encourages active, thoughtful, and equal participation from all comers" (Althaus, 1997). For example, Larkin-Hein (2001) found that online discussions allow students to adopt a more active role in the learning experience and facilitate the 
acquisition of higher order thinking skills and deep learning (Aviv, 2000; Gibbs, 1992; Murphy \& Coleman, 2004; Shapley, 2000). Online discussions allow students to reflect on their responses (Heckman \& Annabi, 2003) and encourage "high levels of cognitive engagement and critical thinking" (Aviv, Erlich, Ravid \& Geva, 2003; Thomas, 2002; Wu \& Hiltz, 2004).

Online discussions provide all students with an equal opportunity to participate, and thus dominant students cannot monopolise the discussion, as can happen in face to face discussions (Ortega, 1997). Moreover, online discussions allow students to interact at their own pace by providing an opportunity to think through their contributions and edit them prior to engaging in the discussion (Biesenbach-Lucas, 2003; Ortega, 1997). In particular, online discussions provide an opportunity for ESL students, who may be reluctant to speak up in a face to face environment, to engage in class discussions (Curtin, 2002; Kahmi-Stein, 2000; Lamy \& Goodfellow, 1999; Murphy \& Coleman, 2004; Ortega, 1997; Warschauer, 1997). Online discussions allow ESL students to overcome linguistic limitations and express concepts in their own words in English (Biesenbach-Lucas, 2003), as well as, "practise the new language of the knowledge community" in a supportive learning environment (Kahmi-Stein, 2000; Wilson \& Stacey, 2004). ESL students often lack the experience of critically engaging with the course content as is required at the tertiary education level (BiesenbachLucas, 2003). Compulsory participation in online discussion could be a mechanism for encouraging these students to participate in a "higher level scholarly discourse" (Rossman, 1999). Hence, these many benefits may prompt educators to consider online discussion as a compulsory part of student assessment, and in particular as a strategy for encouraging greater engagement by, and improved learning outcomes for, ESL students.

Based on the review of the literature which indicates that ESL students, in particular, may benefit from participating in online discussions, the following research questions were developed. Compared with their EFL counterparts, do ESL students perceive online discussion to be more beneficial:

1. for cognitive/ social learning outcomes?

2. for primarily social learning outcomes?

3. for developing graduate attributes?

4. for providing a convenient forum for communication?

\section{Case study: Promotion management course}

Distance education students in an undergraduate course in promotion management at the University of Southern Queensland (USQ) were required to participate on the online discussion board as a compulsory part 
of their assessment (10\% of their final grade). This promotion management course deals with the promotion element of the marketing mix and integrated marketing communication strategies used by organisations to reach their audiences. The primary objectives of the assessment were to replicate the on campus students' tutorial experience, by encouraging greater student engagement, stimulating interaction between the distance education students, and fostering a social and collaborative learning environment in which students could develop meanings by sharing their experiences and perspectives (Jonassen, 1990). Other objectives were to facilitate the development of better electronic communication skills, and to reduce the sense of isolation that distance students sometimes experience.

Students were required to make at least four postings of 100-150 words across ten weekly topics. The topics were specifically designed for the online discussion task in that they allowed a variety of issues to be addressed, gave students an opportunity to share their own experiences, and allowed a range of perspectives to be presented. The required number of postings was restricted to four, due to limited access to the Internet by some groups of students, as well as university resource implications in terms of monitoring the discussion. However, as the students were formally assessed on their best four posting, many students posted on every available topic. Students were asked to share their experiences and perspectives on a given topic by posting either an original comment, responding constructively to another student's contribution, or synthesising a number of students' responses.

Requiring explicit responses ensures that students are reading and responding to other students contributions (Scarce, 1997). Students were provided with a rubric for assessment which explained that their contributions would be evaluated as being excellent, good, sound, limited or minimal, in terms of: (a) the insightfulness of their comments; (b) their understanding of the underlying theory; and (c) their ability to apply the theory to 'real world' marketing situations. The aim was to gain interaction between students and hence the role of the instructor was primarily to assess contributions, rather than to provide feedback or contribute in the open discussion forum. Students were individually emailed feedback on their contributions by the instructor.

\section{Research method}

The research involved an electronic survey toward the end of semester 1, 2005. Respondents were anonymous throughout. Students were asked to report on their previous participation on online course discussion boards, and their perceptions of how beneficial online discussion boards are in terms of achieving key learning outcomes, such as understanding the 
course content, developing learning networks, and seeking advice on assessment items. Students who reported non-participation in online discussion boards in previous courses were asked to identify reasons for their lack of participation.

Students were then asked to report on the extent to which they believed the online discussion assessment item which had been set for this course, had allowed them to achieve beneficial learning outcomes and develop important graduate skills. Students were also asked to indicate their attitude toward the online assessment item on a number of dimensions. Their perceptions were measured on five-point scales, with the items being developed from a review of the literature, as well as, an exploratory study that had been undertaken in a previous offering of the course (Birch, 2004). Comparisons of responses between EFL and ESL students were made to test the research questions and thus identify any differences in perceptions across these two groups.

To improve the response rate, the instructors sent reminder emails to students to encourage them to complete the online survey. Students were advised that their feedback would be valuable in terms of assessing the effectiveness of the online discussion assessment item. The teaching team also advised students that a copy of the findings would be uploaded to the course homepage so that the students could see the results of the survey.

\section{Findings and discussion}

\section{Response rates and respondent profiles}

Of the 161 distance education students enrolled in the course at USQ, seventy $(44 \%)$ responded to the survey. Over half of the respondents $(55 \%)$ indicated that English was not their first language (ESL), and this was reflective of the overall class. The majority of the respondents $(80 \%)$ were females, aged 21-29 years (which reflected the demographic of the total class). The respondents to the survey included both on shore $(40 \%)$ and off shore students $(60 \%)$, and despite being a distance education course, seventy percent of the respondents reported that they were full time students (many students in the course were enrolled with overseas partner colleges). However, $37 \%$ of the respondents also reported that they were full time employed, indicating very heavy workloads for some students. Most of the respondents $(73 \%)$ had completed less than half of the courses in their degree program. However, all students needed to have successfully completed at least one prerequisite course prior to being enrolled in this one; hence it could be assumed that all students had attained an acceptable level of English proficiency. 


\section{Previous participation in online discussions}

Students were asked if they had participated in online discussions in previous courses. Of the $62 \%$ of students who had accessed the online discussion board in previous courses, half of the respondents indicated that they had accessed the online discussion board at least once per fortnight, while about one-third $(29 \%)$ reported that their access had been less than once per month. Of those who had accessed online discussion boards prior to this course, most $(88 \%)$ reported that access had been useful for achieving key learning outcomes, such as understanding the course content, developing learning networks, and seeking advice on assessment items. Thirty-eight percent of the respondents had not participated previously in an online course discussion. Students were provided with a list of possible reasons for non-participation, drawn from previous research (Birch 2004), and were asked to select all the reasons that applied. Table 1 presents the reasons for non-participation in previous course discussions. The two major reasons cited for non-participation were not being required to do so $(38 \%)$, and limited time $(26 \%)$. However, there were some differences relating to participation issues experienced by ESL students, compared to their EFL counterparts, including not being required to do so, having limited time, not considering participation to be necessary or useful, and lack of access to the Internet.

Table 1: Reasons for non-participation in previous course discussion forums across language groups $(\%)$

\begin{tabular}{|l|c|c|}
\hline \multicolumn{1}{|c|}{ Reasons for non-participation } & $\begin{array}{c}\text { EFL (\%) } \\
\mathrm{n}=29\end{array}$ & $\begin{array}{c}\text { ESL (\%) } \\
\mathrm{n}=36\end{array}$ \\
\hline Not required to do so & 38 & 31 \\
\hline Limited time & 26 & 34 \\
\hline Did not consider participation to be necessary & 14 & 7 \\
\hline Did not know there was a discussion forum & 12 & 14 \\
\hline Took too long to access and download & 12 & 14 \\
\hline Did not consider participation to be useful & 10 & 3 \\
\hline Did not feel confident in the online environment & 8 & 10 \\
\hline Not interested in the discussion forum & 8 & 7 \\
\hline Don't like the online environment & 6 & 7 \\
\hline No access to Internet & 6 & 3 \\
\hline Did not know how to use the discussion forum & 4 & 3 \\
\hline No access to computer & 2 & 3 \\
\hline
\end{tabular}

\section{Perceived benefits of online discussions}

To assess the extent to which students perceived online discussion in general to be beneficial, respondents were presented with various attributes of online discussions and asked to indicate on a five-point scale how beneficial each attribute was to them (Table 2). For the purpose of 
analysis, attributes have been grouped as being cognitive/social (reflecting the socio-constructivist approach to learning), social (reflecting the development of a learning community), graduate attributes (reflecting important graduate skills), and attributes associated with convenience (reflecting place and time utility). For the purpose of reporting the findings, responses of "strongly agreed" and "agreed" and "very beneficial" and "beneficial" have been summed throughout this study.

Table 2: Respondents' ratings of various attributes of online discussions across language groups

\begin{tabular}{|l|c|c|c|c|}
\hline \multicolumn{1}{|c|}{ Statement } & $\begin{array}{c}\text { ESL } \\
\text { mean (sd) }\end{array}$ & $\begin{array}{c}\text { EFL } \\
\text { mean (sd) }\end{array}$ & t-test & sig (p) \\
\hline Getting feedback on your ideas and opinions & $1.71(0.99)$ & $1.72(0.85)$ & 0.042 & 0.966 \\
\hline $\begin{array}{l}\text { Learning about other students' views / } \\
\text { perspectives }\end{array}$ & $2.02(0.96)$ & $2.06(0.97)$ & 0.171 & 0.865 \\
\hline Learning from other students' experiences & $2.05(0.96)$ & $2.13(0.95)$ & 0.335 & 0.739 \\
\hline Interacting with the course instructors & $2.20(1.02)$ & $2.06(0.92)$ & -0.533 & 0.596 \\
\hline Sharing your views / perspectives with others & $2.22(0.89)$ & $2.41(1.01)$ & 0.805 & 0.424 \\
\hline Sharing your experiences with others & $2.22(0.91)$ & $2.72(0.88)$ & 2.198 & $0.032^{*}$ \\
\hline $\begin{array}{l}\text { Providing sense of belonging to a community } \\
\text { of learning }\end{array}$ & $2.38(0.99)$ & $2.51(1.15)$ & 0.482 & 0.632 \\
\hline Interacting with other students & $2.51(0.98)$ & $2.46(0.96)$ & -0.203 & 0.840 \\
\hline $\begin{array}{l}\text { Developing closer relationship with course } \\
\text { instructors }\end{array}$ & $2.25(0.99)$ & $2.25(1.00)$ & 0.000 & 1.000 \\
\hline Reducing the feeling of isolation & $2.69(1.09)$ & $2.03(1.05)$ & 2.464 & $0.016^{*}$ \\
\hline Meeting other students & $2.80(0.92)$ & $3.03(0.92)$ & 1.004 & 0.319 \\
\hline Developing friendships with other students & $2.85(0.87)$ & $3.10(1.08)$ & 1.006 & 0.318 \\
\hline $\begin{array}{l}\text { Developing more effective electronic } \\
\text { communication skills }\end{array}$ & $2.02(1.10)$ & $2.50(1.17)$ & 1.650 & 0.104 \\
\hline $\begin{array}{l}\text { Becoming more confident operating in the } \\
\text { electronic environment }\end{array}$ & $2.33(1.09)$ & $2.51(1.15)$ & 0.657 & 0.513 \\
\hline $\begin{array}{l}\text { Providing forum for communication at a } \\
\text { place that is convenient }\end{array}$ & $2.30(1.14)$ & $2.03(0.88)$ & -1.033 & 0.306 \\
\hline $\begin{array}{l}\text { Providing a forum for communication at a } \\
\text { time that is convenient }\end{array}$ & $2.25(1.02)$ & $2.10(0.85)$ & -0.615 & 0.541 \\
\hline
\end{tabular}

Scale: five point scale with 1 = very beneficial; 2 = quite beneficial; 3 = beneficial; $4=$ not very beneficial; $5=$ not at all beneficial, $t=t$ score, $\mathrm{p}=$ significance,

* = significant at the $95 \%$ confidence level

Cognitive/social attributes of online discussions that respondents deemed to be particularly beneficial, included gaining feedback on ideas and opinions $(94 \%)$, learning about other students' views and perspectives $(93 \%)$, learning from other students' experiences (93\%), and interacting with course instructors $(93 \%)$. No significant differences were found between native speakers of English and ESL students. Other cognitive/social attributes that were also considered to be beneficial, included sharing views and perspectives (90\%) and experiences (85\%) with others, providing 
a sense of belonging to a community of learning (84\%), and interacting with other students $(86 \%)$. Apart from ESL students rating the attribute of sharing their experiences with others more highly $\left(\mathrm{t}_{(63)}=2.198, \mathrm{p}=0.032\right)$ than their EFL counterparts, no other significant differences were found between EFL and ESL students.

The primarily social attributes of online discussions that were deemed to be beneficial included developing closer relationships with course instructors (90\%), reducing feelings of isolation (82\%), meeting $(67.5 \%)$ and developing friendships $(68 \%)$ with other students. In particular, ESL students agreed more strongly than EFL students that online discussions are beneficial for reducing feelings of isolation $\left(\mathrm{t}_{(63)}=2.464, \mathrm{p}=0.016\right)$. This in keeping with findings from previous research which has also revealed that social interaction is cited as a major benefit of discussion board posting by ESL students (Weasenforth et al., 2002). Further, students perceived that online discussions are beneficial in terms of facilitating the development of important graduate attributes, including developing more effective electronic communication skills $(85 \%)$, and becoming more confident with operating in the electronic environment $(79 \%)$. Respondents also indicated that online discussions are beneficial in terms of providing a forum for communication at both a time (94\%) and a place (88\%) that is convenient to them. No significant differences were found across language groups with respect to graduate attributes or convenience items.

\section{Students' perceptions of the online discussion assessment item}

Students were asked to respond more specifically on the extent to which they agreed that the online discussion assessment item (ODAI), which had been developed and set for the promotion management course, had allowed them to achieve beneficial learning outcomes. Once again for analysis the learning outcomes have been grouped as being primarily cognitive, a blend of social and cognitive, or primarily social (Table 3).

The main cognitive learning outcomes that respondents agreed were achieved through the online discussion assessment item included applying the theory to real world examples $(86 \%)$, thinking more deeply about key concepts $(80 \%)$, and understanding key concepts $(77 \%)$. These findings confirm previous research which found that there are significant cognitive benefits to be gained from online discussions including improved learning skills and quality of learning (Harasim, 1987; Larkin-Hein, 2001; Thomas, 2002; Wu \& Hiltz, 2004).

In line with the socio-constructivist approach to learning, outcomes which were both social and cognitive in nature included gaining feedback on opinions from instructors (92\%) and other students (76\%), sharing views 
and perspectives with others $(85 \%)$, and sharing experiences with others $(80 \%)$. These findings support Vygotsky's (1978) social learning concept and the zone of proximal development in which learners are purported to benefit from interactions with and support from more able peers. While many respondents neither agreed nor disagreed with statements concerning the primarily social learning outcomes of the online discussion assessment item, some respondents did agree that it had provided them with an opportunity to meet (42\%) and develop closer relationships (29\%) with other students. In particular, ESL students agreed more strongly than EFL students that the online discussion assessment item had provided them with an opportunity to meet $\left(\mathrm{t}_{(61)}=2.317, \mathrm{p}=0.024\right)$ and develop closer relationships $\left(\mathrm{t}_{(62)}=3.321, \mathrm{p}=0.002\right)$ with other students.

Table 3: Perceptions of cognitive and social outcomes of the ODAI across language groups

\begin{tabular}{|c|c|c|c|c|c|}
\hline \multicolumn{2}{|r|}{ Learning outcome } & \multirow{2}{*}{\begin{tabular}{|c|} 
ESL \\
mean $(\mathrm{sd})$ \\
$1.74(0.70)$
\end{tabular}} & \multirow{2}{*}{$\begin{array}{c}\text { EFL } \\
\text { mean }(\mathrm{sd}) \\
1.85(0.97)\end{array}$} & \multirow{2}{*}{$\frac{t}{0.542}$} & \multirow{2}{*}{$\begin{array}{c}\mathrm{p} \\
0.589\end{array}$} \\
\hline \multirow[t]{4}{*}{$\begin{array}{l}\text { Cognitive } \\
\text { outcomes }\end{array}$} & $\begin{array}{l}\text { The ODAI allowed me to apply the } \\
\text { theory to real world examples }\end{array}$ & & & & \\
\hline & $\begin{array}{l}\text { The ODAI encouraged me to think } \\
\text { more deeply about key concepts }\end{array}$ & $1.77(0.79)$ & $2.03(1.10)$ & 1.085 & 0.282 \\
\hline & $\begin{array}{l}\text { The ODAI helped me to understand } \\
\text { key concepts }\end{array}$ & $1.86(0.72)$ & $2.14(0.80)$ & 1.473 & 0.146 \\
\hline & $\begin{array}{l}\text { The ODAI allowed me to assess my } \\
\text { progress relative to other students }\end{array}$ & $2.17(0.85)$ & $2.53(0.83)$ & 1.693 & 0.096 \\
\hline \multirow[t]{4}{*}{$\begin{array}{l}\text { Social and } \\
\text { cognitive } \\
\text { outcomes }\end{array}$} & $\begin{array}{l}\text { The ODAI provided me with an } \\
\text { opportunity to gain feedback on my } \\
\text { opinions from my instructors }\end{array}$ & $1.74(0.56)$ & $1.67(0.81)$ & -0.369 & 0.713 \\
\hline & $\begin{array}{l}\text { The ODAI gave me an opportunity } \\
\text { to share my views / perspectives }\end{array}$ & $1.80(0.62)$ & $1.75(0.70)$ & -0.335 & 0.739 \\
\hline & $\begin{array}{l}\text { The ODAI provided me with an } \\
\text { opportunity to gain feedback on my } \\
\text { opinions from other students }\end{array}$ & $1.91(0.76)$ & $2.28(0.93)$ & 1.729 & 0.089 \\
\hline & $\begin{array}{l}\text { The ODAI allowed me to share my } \\
\text { experiences with others }\end{array}$ & $2.00(0.64)$ & $2.07(0.66)$ & 0.433 & 0.667 \\
\hline \multirow[t]{2}{*}{$\begin{array}{l}\text { Social } \\
\text { outcomes }\end{array}$} & $\begin{array}{l}\text { The ODAI provided me with an } \\
\text { opportunity to meet other students } \\
\text { in the course }\end{array}$ & $2.48(0.78)$ & $3.00(0.98)$ & 2.317 & $0.024^{*}$ \\
\hline & $\begin{array}{l}\text { The ODAI allowed me to develop } \\
\text { closer relationships with other } \\
\text { students in the course }\end{array}$ & $2.61(0.83)$ & $3.32(0.86)$ & 3.321 & $0.002^{*}$ \\
\hline
\end{tabular}

Scale: five-point scale with 1 = very beneficial; 2 = quite beneficial;

$3=$ beneficial; $4=$ not very beneficial; $5=$ not at all beneficial, $\mathrm{t}=\mathrm{t}$ score,

$\mathrm{p}=$ significance, ${ }^{*}=$ significant at the $95 \%$ confidence level

To assess the potential of the online discussion assessment item to facilitate the development of graduate attributes, students were asked to respond on 
the extent to which they agreed that the online discussion assessment item had allowed the development of a range of desired graduate skills (Table 4). Respondents agreed that some important graduate skills had been developed through participation in the online discussion assessment item, including opportunities to improve their ability to present their thoughts and opinions in writing $(79 \%)$, keeping up to date with their study $(71 \%)$, becoming more confident in using online discussion boards $(69 \%)$, and enabling the development of more effective electronic communication skills $(69 \%)$. In particular, ESL students agreed more strongly than EFL students that the online discussion assessment item had encouraged them to keep up to date with their studies $\left(\mathrm{t}_{(62)}=2.239, \mathrm{p}=0.029\right)$.

Table 4: Perceptions of the ability of the ODAI to develop important graduate skills across language groups

\begin{tabular}{|l|l|l|l|c|}
\hline \multicolumn{1}{|c|}{ Graduate skill } & \multicolumn{1}{c|}{$\begin{array}{c}\text { ESL } \\
\text { mean (sd) }\end{array}$} & $\begin{array}{c}\text { EFL } \\
\text { mean (sd) }\end{array}$ & t & p \\
\hline $\begin{array}{l}\text { The ODAI provided me with an opportun- } \\
\text { ity to improve my ability to present my } \\
\text { thoughts and opinions in writing }\end{array}$ & $1.91(0.70)$ & $2.07(0.76)$ & 0.848 & 0.400 \\
\hline $\begin{array}{l}\text { The ODAI encouraged me to keep up to } \\
\text { date with my study }\end{array}$ & $1.83(0.81)$ & $2.35(1.06)$ & 2.239 & $0.029^{*}$ \\
\hline $\begin{array}{l}\text { The ODAI helped me to become more } \\
\text { confident in using online discussion boards }\end{array}$ & $2.05(0.83)$ & $2.39(0.99)$ & 1.454 & 0.151 \\
\hline $\begin{array}{l}\text { The ODAI helped me to develop more } \\
\text { effective electronic communication skills }\end{array}$ & $2.11(0.75)$ & $2.53(1.07)$ & 1.827 & 0.073 \\
\hline
\end{tabular}

Scale: Five-point Likert scale with $1=$ SA strongly agree and $5=$ SD strongly

disagree, $\mathrm{t}=\mathrm{t}$ score, $\mathrm{p}=$ significance, ${ }^{*}=$ significant at the $95 \%$ confidence level

\section{Students' attitudes toward online discussions}

Respondents were asked to report on their attitudes toward aspects of online discussions in general (Table 5). Respondents agreed that having been required to participate in the online discussion, they would now be more likely to voluntarily participate in future courses $(56 \%)$. While limited time was cited as a major reason for non-participation in previous courses, only 38 percent of the respondents agreed that it was difficult to find time to access the course discussion board. While 43 percent of the respondents disagreed that they did not like being required to participate, only 31 percent agreed that they would not participate if they were not required to do so. Moreover, many respondents $(41 \%)$ agreed that 'online discussions should be compulsory', with a further 33 percent neither agreeing nor disagreeing with this statement. There were no significant differences found between EFL and ESL students. 
Table 5: Attitudes toward online discussions across language groups

\begin{tabular}{|l|c|c|c|c|}
\hline \multicolumn{1}{|c|}{ Attitude statement } & $\begin{array}{c}\text { ESL } \\
\text { mean (sd) }\end{array}$ & $\begin{array}{c}\text { EFL } \\
\text { mean (sd) }\end{array}$ & t & $\mathrm{p}$ \\
\hline $\begin{array}{l}\text { Having been required to participate in the online } \\
\text { discussion in this course, I am now more likely to } \\
\text { voluntarily participate in future courses }\end{array}$ & $2.45(0.95)$ & $2.75(1.04)$ & 1.165 & 0.248 \\
\hline $\begin{array}{l}\text { I found it difficult to find time to access the } \\
\text { course discussion board }\end{array}$ & $2.86(1.07)$ & $2.96(1.23)$ & 0.358 & 0.722 \\
\hline Online discussions should be compulsory & $2.86(0.96)$ & $3.14(1.14)$ & 1.070 & 0.289 \\
\hline $\begin{array}{l}\text { If I was not required to, I would not participate } \\
\text { in online discussions }\end{array}$ & $3.31(0.86)$ & $2.96(0.99)$ & -1.488 & 0.142 \\
\hline $\begin{array}{l}\text { I did not like being required to participate in the } \\
\text { online discussions }\end{array}$ & $3.31(0.93)$ & $3.17(1.12)$ & -0.524 & 0.602 \\
\hline
\end{tabular}

Scale: Five-point Likert scale with $1=\mathrm{SA}$ strongly agree and $5=\mathrm{SD}$ strongly disagree, $\mathrm{t}=\mathrm{t}$ score, $\mathrm{p}=$ significance, ${ }^{*}=$ significant at the $95 \%$ confidence level

\section{Students' attitudes towards the online discussion assessment item}

Respondents were then asked more specifically about their attitudes toward the online discussion assessment item (Table 6). On the positive side, less than one quarter of the respondents reported that they did not like the online discussion assessment item (22\%). Indeed, most agreed that they enjoyed the online discussion assessment item (59\%) and considered it to be a good idea $(73 \%)$, while almost half of the respondents agreed that it was a novel assessment item $(45 \%)$, and the majority agreed that it should be continued for future offerings of the course $(72 \%)$.

Table 6: Attitudes toward the online discussion assessment item across language groups

\begin{tabular}{|l|c|c|c|c|}
\hline \multicolumn{1}{|c|}{ Attitude toward online discussion item } & $\begin{array}{c}\text { ESL } \\
\text { mean (sd) }\end{array}$ & $\begin{array}{c}\text { EFL } \\
\text { mean (sd) }\end{array}$ & $\mathrm{t}$ & $\mathrm{p}$ \\
\hline I did not like the ODAI & $3.69(1.09)$ & $3.35(1.06)$ & -1.242 & 0.219 \\
\hline $\begin{array}{l}\text { I experienced some difficulty accessing } \\
\text { the course discussion board }\end{array}$ & $3.05(1.08)$ & $3.89(0.95)$ & 3.204 & $0.002^{*}$ \\
\hline $\begin{array}{l}\text { The discussion board took too long to } \\
\text { download }\end{array}$ & $3.27(1.03)$ & $3.78(0.73)$ & 2.202 & $0.031^{*}$ \\
\hline The ODAI is a good idea & $1.94(0.96)$ & $1.96(0.88)$ & 0.091 & 0.928 \\
\hline $\begin{array}{l}\text { The ODAI should be continued for future } \\
\text { offerings of this course }\end{array}$ & $2.11(1.00)$ & $1.92(0.81)$ & -0.780 & 0.438 \\
\hline $\begin{array}{l}\text { I enjoyed the ODAI } \\
\text { The ODAI is a novel assessment item }\end{array}$ & $2.30(0.85)$ & $2.50(0.96)$ & 0.854 & 0.396 \\
\hline $\begin{array}{l}\text { The ODAI was a time consuming } \\
\text { assessment item }\end{array}$ & $2.77(1.16)$ & $3.07(1.15)$ & 1.020 & 0.312 \\
\hline $\begin{array}{l}\text { I had problems meeting the deadlines for } \\
\text { the discussion topics }\end{array}$ & $3.00(1.19)$ & $2.89(1.03)$ & -0.377 & 0.707 \\
\hline
\end{tabular}

Scale: Five-point Likert scale with $1=$ SA strongly agree and $5=$ SD strongly disagree, $\mathrm{t}=\mathrm{t}$ score, $\mathrm{p}=$ significance, ${ }^{*}=$ significant at the $95 \%$ confidence level 
Only $27 \%$ of the respondents agreed that they had experienced some difficulty accessing the course discussion board, while only $20 \%$ of respondents indicated that the board took too long to download. ESL students were more likely to agree than EFL students that they experienced difficulty accessing the course discussion board $\left(\mathrm{t}_{(61)}=3.204, \mathrm{p}=0.002\right)$, and that the discussion board took too long to download $\left(t_{(62)}=2.202, p=0.031\right)$. On the negative side, $38 \%$ of respondents agreed that the online discussion assessment item was time consuming, and 39\% agreed they had problems meeting the deadlines for posting on the weekly discussion topics.

\section{Limitations, further research and implications}

This study was restricted to one undergraduate marketing course in an Australian university, and thus should be replicated for other courses using online discussions for assessment purposes and having both ESL and EFL students enrolled.

The findings of this study indicate that both ESL and EFL students perceive that valuable benefits are gained from participation in asynchronous online discussions. In particular, respondents perceived significant cognitive benefits and the ability to develop important graduate attribute skills via online discussions. Online discussions support a socio-constructivist approach to learning by yielding a number of outcomes which are both social and cognitive in nature. To a lesser extent the results indicate that online discussions yield some primarily social learning outcomes.

One of the key aims of the assessment was to get students to interact with one another rather than just with the instructor. Two of the four postings required students to make constructive comments on another student's contribution and also to provide a synthesis of a number of students. This raised the exercise beyond purely posting reflections, to allow some degree of student-student interaction. Ideally, with greater instructor resources or a smaller cohort of students, a greater number of contributions requiring increased interaction with other students could be specified.

The focus of this study was to determine whether online discussion could be used as a mechanism for engaging ESL students and whether they perceived greater benefits than their EFL counterparts. In particular, ESL students reported the benefits of posting to the discussion board in terms of sharing their experiences with others and reducing their feelings of isolation. Further, when considering social outcomes, ESL students agreed more strongly than their EFL counterparts that participation on the discussion board provided them with an opportunity to meet and develop a closer relationship with other students in the course, and encouraged them to keep up with their studies. 
At the end of semester, the teaching team met to discuss the effectiveness of the online discussion assessment item. The benefits of assessment item were apparent to the teaching team in that students were more engaged with the course and its content over the semester, and their ability to express their thoughts, apply the theory to the real world and use theory to support their arguments improved, as evidenced by most students gaining higher marks for contributions made later in the semester. The instructors were also able to identify students at risk, as well as key problem areas, such as the lack of use of theory to support arguments early in the semester. This gave a chance to provide early feedback to students on their performance and where they needed to improve. Another pleasing outcome was that there were fewer incidents of failure to cite and plagiarism in their major written report. The teaching team noted that the ESL students appeared to have greater confidence at expressing their ideas in their own words, rather than reciting word for word from other sources. However, the teaching team also acknowledged that this assessment item was resource intensive and time consuming.

The findings of this study indicate that some of the barriers to online discussions that have previously been reported in the literature, such as limited access to the Internet and the time it takes to download the discussion board, may now not be as problematic as they have been in the past. However, it should be noted that in this study ESL students experienced greater difficulties than EFL students with respect to access to the course discussion board and download time. Nevertheless, the findings indicate that both ESL and EFL students are receptive to online discussion being set as part of their assessment, and this supports their perception that a range of valuable learning outcomes can be attained through participation in online discussion.

\section{Conclusions}

The findings in this study indicate that both ESL and EFL students perceive a number of benefits can be gained from participation in online discussions, and both groups are receptive to online discussions being set as part of the assessment. ESL students consider online discussions to be beneficial for achieving a range of cognitive and social learning outcomes, as well as developing some important graduate skills and for providing a convenient forum for communication. ESL students reported that they enjoyed participating in the online discussions and considered online discussion assessment to be a good idea. The findings of this study may encourage more tertiary educators to consider compulsory online discussion as a tool for encouraging collaborative learning and for facilitating a socio-constructivist approach, in particular with ESL students. 


\section{Acknowledgements}

The authors wish to acknowledge the Faculty of Business at the University of Southern Queensland for supporting this research project, and Debbie Rhodes who assisted with the technical aspects of the electronic survey.

\section{References}

Althaus, S. (1997). Computer-mediated communication in the university classroom: An experiment with on-line discussions. Communication Education, 46, 158-174. [verified 17 Jun 2007] http: / t teachpol.tcnj.edu/conference_papers / _manuscripts/sal96a.pdf

Aviv, R. (2000). Educational performance of ALN via content analysis. Journal of Asynchronous Learning Networks, 4(2). [verified 17 Jun 2007] http: / / www.sloanc.org/publications/jaln/v4n2/v4n2_aviv.asp

Aviv, R., Erlich, Z., Ravid, G. \& Geva, A. (2003). Network analysis of knowledge construction in asynchronous learning networks. Journal of Asynchronous Learning Networks, 7(3). [verified 17 Jun 2007] http: / / www.sloanc.org/publications/jaln/v7n3/index.asp

Berge, Z. \& Collins, M. (1993). Computer conferencing and online education. The Arachnet Electronic Journal of Virtual Culture, 1(3). [verified 17 Jun 2007] http:/ / emoderators.com/ papers/bergev1n3.html

Biesenbach-Lucas, S. (2003). Asynchronous discussion groups in teacher training classes: Perceptions of native and non-native students. Journal of Asynchronous Learning Networks, 7(3), 24-46. [verified 17 Jun 2007] http:/ / www.sloanc.org/publications/jaln/v7n3/v7n3_biesenbach-lucas.asp

Birch, D. (2004). Participation in asynchronous online discussions for student assessment. Paper presented at the Australia and New Zealand Marketing Academy Conference (ANZMAC), Wellington, New Zealand, 29 November - 1 December. http:/ / eprints.usq.edu.au/archive/00002663/01/Birch_2004_ANZMAC.pdf

Bruner, J. (1990). Constructivist theory: Explorations in learning and instruction. In The Theory into Practice (TIP) Database. http: / / tip.psychology.org/bruner.html

Curtin, J. (2002). WebCT and online tutorials: New possibilities for student interaction. Australian Journal of Educational Technology, 18(1), 110-126. http: / / www.ascilite.org.au/ajet/ajet18/ curtin.html

Gibbs, G. (1992). Active learning in structured lectures. In G. Gibbs \& A. Jenkins (Eds.), Teaching large classes in higher education. London: Kogan Page.

Goodyear, P. (2001). Effective networked learning in higher education: Notes and guidelines. In Centre for Studies in Advanced Learning Technology: Lancaster University. [verified 17 Jun 2007] http: / / csalt.lancs.ac.uk/jisc/guidelines_final.doc

Harasim, L. M. (1987). Teaching and learning on-line: Issues in computer-mediated graduate courses. Canadian Journal of Educational Communication, 16(2), 117-135. 
Hausfather, S. J. (1996). Vygotsky and schooling: Creating a social contest for learning. Action in Teacher Education, 18, 1-10.

Heckman, R. \& Annabi, H. (2003). A content analytic comparison of FTF and ALN case study discussions. Paper presented at the 36th International Conference on System Sciences, Hawaii. [verified 17 Jun 2007] http: / / csdl2.computer.org/ comp/proceedings/hicss/2003/1874/01/187410003a.pdf

Jonassen, D. (1990). Designing constructivist learning environments. In C. M. Reigeluth (Ed.), Instructional design theories and models. New Jersey: Lawrence Erlbaum Associates.

Kahmi-Stein, L. (2000). Looking to the future of TESOL teacher education: Webbased bulletin board discussions in a method course. TESOL Quarterly, 34(3), 423-455.

Kolb, D. A. (2004). Experiential learning: Experience as the source of learning and development. Englewood Cliffs, NJ: Prentice Hall.

Lamy, M.-N. \& Goodfellow, R. (1999). "Reflective conversation" in the virtual classroom. Language Learning and Technology, 2(2), 43-61.

Larkin-Hein, T. (2001). On-line discussions: A key to enhancing student motivation and understanding? 31st ASEE/IEEE Frontiers in Education Conference, Reno, NV. [verified 17 Jun 2007] http: / / fie.engrng.pitt.edu / fie2001/ papers/1121.pdf.

Markel, S. L. (2001). Technology and education discussion forums: It's in the response. Online Journal of Distance Learning Administration, 4(2). [verified 17 Jun 2007] http: / / www.westga.edu/ distance/ojdla/ summer42 / markel42.html

Moore, M. G. (1989). Three types of interaction. American Journal of Distance Education, 3(2), 1-6.

Murphy, E. \& Coleman, E. (2004). Graduate students' experiences of challenges in online asynchronous discussions. Canadian Journal of Learning and Teaching, 30(2). http:/ / www.cjlt.ca/content/vol30.2 / cjlt30-2_art-2.html

Ortega, L. (1997). Processes and outcomes in networked classroom interaction: Defining the research agenda for L2 computer-assisted classroom discussion. Language Learning and Technology, 1(1), 82-93.

Rossman, M. H. (1999). Successful online teaching using an asynchronous learner discussion forum. Journal of Asynchronous Learning Networks, 3(2) 1-8. [verified 17 Jun 2007] http: / / www.sloan-c.org/publications/jaln/v3n2/v3n2_rossman.asp

Scarce, R. (1997). Using electronic mail discussion groups to enhance students' critical thinking skills. The Technology Source, July. [verified 17 Jun 2007] http: / / technologysource.org/article/using_electronic_mail_discussion_groups _to_enhance_students_critical_thinking_skills /

Shapley, P. (2000). On-line education to develop complex reasoning skills on organic chemistry. Journal of Asynchronous Learning Networks, 4(2). [verified 17 Jun 2007] http: / / www.sloan-c.org/publications/jaln/v4n2/v4n2_shapley.asp

Stacey, E. (2002). Learning links online: Establishing constructivist and collaborative learning environments. In S. McNamara \& E. Stacey (Eds.), Untangling the web: 
Establishing learning links. Proceedings ASET Conference 2002. Melbourne, 7-10 July. http: / / www.ascilite.org.au/ aset-archives / confs / 2002/ stacey.html

Thomas, M. J. W. (2002). Learning with incoherent structures: The space of online discussion forums. Journal of Computer Assisted Learning, 18(3), 351-366.

Turcotte, S. \& Laferriere, T. (2004). Integration of an online discussion forum in a campus-based undergraduate biology class. Canadian Journal of Learning and Technology, 30(2). http: / / www.cjlt.ca / content/vol30.2/ cjlt30-2_art-4.html

Vygotsky, L. S. (1978). Mind and society: The development of higher mental processes. Cambridge, MA: Harvard University Press.

Warschauer, M. (1997). Computer-mediated collaborative learning: Theory and practice. The Modern Language Journal, 81(4), 470-481. [preprint verified 17 Jun 2007] http: / / www.gse.uci.edu / faculty / markw / cmcl.html

Weasenforth, D., Biesenbach-Lucas, S. \& Meloni, C. (2002). Realizing constructivist objectives through collaborative technologies: Threaded discussions. Language Learning and Technology, 6(3), 58-86. [verified 17 Jun 2007] http: / /llt.msu.edu/vol6num3/pdf/weasenforth.pdf

Whatley, J. \& Bell, F. (2003). Discussion across borders: Benefits for collaborative learning. Educational Media International, 40(1/2), 139-152.

Wilson, G. \& Stacey, E. (2004). Online interaction impacts on learning: Teaching the teachers to teach online. Australasian Journal of Educational Technology, 20(1), 3348. http: / / www.ascilite.org.au/ajet/ajet20/wilson.html

Wu, D. \& Hiltz, S. R. (2004). Predicting learning from asynchronous online discussions. Journal of Asynchronous Learning Networks, 8(2), 139-152. http: / / www.sloan-c.org/publications/jaln/v8n2/v8n2_wu.asp

Dawn Birch is a Senior Lecturer in the School of Management and Marketing at the University of Southern Queensland. Dawn has published in the areas of education, domestic barter, international advertising, services marketing and shopping centre management. Her current research focuses on the adoption and integration of educational technology for developing multi-modal distance education courses.

Dawn Birch, School of Management and Marketing, Faculty of Business, University of Southern Queensland, Toowoomba Qld 4350, Australia. Email: birch@usq.edu.au Web: http: / /www.usq.edu.au/users/birch

Michael Volkov is a Lecturer in the Bowater School of Management and Marketing in the Faculty of Business and Law at Deakin University, Australia. Michael's research interests are in the areas of education, promotion management and consumer behaviour. His research has been published in journals in the USA, Europe, and Australia and online.

Michael Volkov, Bowater School of Management and Marketing, Faculty of Business and Law, Deakin University, Waurn Ponds Vic 3217, Australia. Email: michael.volkov@deakin.edu.au 